\title{
PENGEMBANGAN MODEL MOTIVASI JUMANIOR (JURU PEMANTAU JENTIK JUNIOR) DALAM PERILAKU PSN (PEMBERANTASAN SARANG NYAMUK) AEDES AEGEPTY BERBASIS INTEGRASI MODEL LAWRANCE GREEN DAN Mc. CLELLEAND
}

\author{
Nian Afrian, Dhina Widayati, Dwi Setyorini \\ Sekolah Tinggi Ilmu Kesehatan Karya Husada Kediri, Jl. Soekarno Hatta 7 Pare, Kediri \\ Email: nian.afrian@yahoo.co.id
}

\begin{abstract}
Dengue fever is a disease in humans caused by a virus that infects an estimated 50 million people in the tropics and sub-tropics every year. Aedes aegypti is the main vector of the disease that has a high adaptability to cans in breeding. Various attempts have been made to reduce the incidence of this disease, including PSN (mosquito nest elimination), fumigation, and abatisasi but in fact until now the incidence of dengue fever is still quite high. The purpose of this study to determine the relationship of knowledge and attitude with motivation of Jumanior to elimination nest mosquito in SD NU and Nurul Islam Pare. This research method using correlational design with cross sectional study. The sample in this study is Jumanior (elementary school students as larva monitoring juniors) of 40 people obtained by purposive sampling. The dependent variable are the knowledge and attitudes, independent variable is Jumanior's motivation measured in the implementation of PSN by questionnaire. Data analized with a statistical test Chi Square. The results showed relationship between the level of knowledge and motivation with strong relationships and a positive direction $(\mathrm{cc}=0.733$ and $\mathrm{p}$-value $=0.002$ ) and relationship between attitude and motivation with the power relationships in a strong category, positive direction, $(\mathrm{cc}=0.724$ and $\mathrm{p}$ value $=$ 0.014). Jumanior with good knowledge about the prevention of dengue fever will affect the attitude which will lead to Jumanior in implementing PSN. PSN should be included in the material in UKS or extracurricular engaged in the health sector, so that it can be a medium of information for students who play an important role in this regard as change agent in the home environment and health to maintain a healthy school environment.
\end{abstract}

Abstrak: Demam berdarah merupakan penyakit pada manusia akibat virus yang diperkirakan menjangkiti 50 juta jiwa di wilayah tropis dan sub tropis setiap tahunnya. Aedes aegepty adalah vektor utama pada penyakit ini yang memiliki tingkat adaptasi tinggi terhadap kaleng dalam perkembangbiakannya. Berbagai upaya telah dilakukan untuk menurunkan angka kejadian penyakit ini, diantaranya PSN (Pemberantasan Sarang Nyamuk), fumigasi, dan abatisasi namun kenyataannya sampai saat ini angka kejadian DBD masih cukup tinggi. Tujuan penelitian ini untuk mengetahui hubungan pengetahuan dan sikap dengan motivasi Jumanior dalam tindakan PSN di SD NU dan Nurul Islam Pare. Metode penelitian ini menggunakan rancangan correlational dengan pendekatan Cross Sectional Study. Sampel dalam penelitian ini adalah Jumanior (siswa SD sebagai juru pemantau jentik junior) berjumlah 40 orang yang diperoleh melalui purposive sampling. Variabel dependen adalah pengetahuan dan sikap, variabel independen adalah motivasi Jumanior dalam pelaksanaan PSN yang diukur menggunakan kuesioner. Data yang diperoleh 
di uji statistik menggunakan Chi Square. Hasil penelitian menunjukkan ada hubungan antara pengetahuan dan motivasi dengan tingkat hubungan kuat dan arah positif, ( $\mathrm{cc}=0,733$ dan pvalue $=0,002)$ dan ada hubungan antara sikap dan motivasi dengan kekuatan hubungan dalam ketagori kuat, arah positif $(\mathrm{cc}=0,724$ dan $\mathrm{p}$ value $=0,014)$. Pengetahuan Jumanior yang baik tentang pencegahan DBD akan mempengaruhi sikap Jumanior yang akan medorong dalam melaksanakan PSN. Kegiatan PSN sebaiknya dimasukkan dalam materi UKS atau ekstrakurikuler yang bergerak di bidang kesehatan, sehingga dapat menjadi media informasi bagi siswa yang dalam hal ini berperan penting sebgai change agent kesehatan di lingkungan rumah maupun sekolah untuk menjaga kesehatan lingkungan.

Kata kunci : Pemberantasan Sarang Nyamuk, Jumanior, Pengetahuan, Sikap, Motivasi

\section{PENDAHULUAN}

Demam berdarah

(DBD)

merupakan penyakit pada manusia akibat virus yang diperkirakan menjangkiti 50 juta jiwa di wilayah tropis dan sub tropis setiap tahunnya (WHO, 2002). DBD merupakan salah satu jenis penyakit menular akut yang menjadi masalah kesehatan dunia terutama pada Negara-negara berkembang termasuk Indonesia. DBD menjadi masalah kesehatan di Indonesia yang menimbulkan dampak sosial maupun ekonomi sering menimbulkan keresahan masyarakat karena perjalanan penyakitnya yang cepat dan dapat menyebabkan kematian dalam waktu singkat. Sampai saat ini yang jadi vektor utama yaitu nyamuk Aedes aegypti. Peningkatan insidensi dan penyebarluasan DBD tersebut diduga erat kaitannya dengan kepadatan vektor yang sangat tinggi dan didukung dengan meningkatnya mobilitas penduduk oleh karena meningkatnya sarana transportasi dalam kota maupun luar kota.

Pemerintah Provinsi Jawa

Timur menetapkan 11 daerah di Jawa Timur berstatus Kejadian Luar Biasa (KLB) penyakit Demam Berdarah (DB). Hal ini terkait sampai hari Minggu (25 Januari 2015) angka penderita demam berdarah di 38
Kabupaten/Kota di Jatim saat ini sudah mencapai 1.054 penderita, dengan 25 penderita di antaranya meninggal dunia. Sedangkan di Wilayah Kabupaten Kediri sebagaimana disampaikan Kepala Dinas Kesehatan Kabupaten Kediri, dr.Adi Laksono, MM. "sampai saat ini (Senin, 26 Januari 2015) tercatat 87 kasus dengan 2 meninggal". Berdasarkan kelompok umur yang terjangkit penyakit DBD adalah anak usia sekolah usia dasar yaitu usia 5-14 tahun ( Dinkes Kab. Kediri, 2015).

Cara penularan penyakit DBD adalah melalui gigitan nyamuk Aedes Aegypti yang mengigit penderita DBD kemudian ditularkan kepada orang sehat. Penderita DBD baik yang masih sakit maupun carier berpotensi untuk menularkan penyakitnya kepada orang lain. Maka upaya pencegahan yang dapat di lakukan adalah dengan memutus mata rantai penularan penyakit $\mathrm{BDB}$, karena dapat di ketahui bahwa virus dengue penyebab penyakit DBD di tularkan dari satu orang ke orang lain melalui perantara gigitan nyamuk Aedes Aegepty. Oleh karenanya upaya pencegahan penyakit DBD dapat dilakukan melalaui pemberantasan sarang nyamuk DBD oleh seluruh lapisan masyarakat di rumah-rumah dan tempat-tempat umum serta 
lingkungannya masing-masing secara terus menerus. Angka bebas jentik (ABJ) sebagai indikator kepadatan vektor DBD dapat mengevaluasi kegiatan Pemberantasan sarang Nyamuk dan Perilaku Masyarakat terhadap DBD dimana angka tersebut diharapkan lebih dari 95\% (Hardayati W, Mulyadi A, Daryono, 2013).

Kelompok Anak merupakan bagian kelompok masyarakat yang mempunyai peran strategis dalam masyarakat karena jumlahnya sekitar $20 \%$ dari penduduk Indonesia. Peran serta Anak usia sekolah dalam Jumanior (Jumatik Yunior) yang berada di Kecamatan Pare Kabupaten Kediri kurang optimal dan cenderung belum terbentuk. Jumanior diharapkan sebagai change agent di Sekolah menyebarkan informasi tentang PSN (Pemberantasan Sarang Nyamuk) di Sekolah maupun di Lingkungan rumah masing-masing. Pemberantasan sarang nyamuk secara umum adalah melakukan gerakan $3 \mathrm{M}$ yaitu menguras bak air. Menutup tempat yang mungkin menjadi sarang biak nyamuk. Di tempat penampungan air seperti bak mandi diberikan insektisida yang membunuh larva nyamuk seperti abate. Ini bisa mencegah perkembangbiakan nyamuk selama beberapa minggu tapi pemberiannya harus diulang setiap periode tertentu (Widodo Judarwanto, 2007)

Namun demikian hingga saat ini upaya pemberantasan vector DBD yang telah dilakukan tersebut belum memperlihatkan hasil yang optimal sehingga kasus DBD masih tinggi dan hal ini terbukti dengan masih tingginya angka kejadian DBD di wilayah Kecamatan Pare dan masih rendahnya, angka bebas jentik (ABJ) yaitu < $95 \%$. Ini menunjukkan kemungkinan terjadi kesenjangan yang sangat lebar antara program PSN-3M-Plus untuk mencegah DBD. Hal ini menunjukkan bahwa perilaku masyarakat terhadap pemberantasan sarang nyamuk masih sangat kurang sehingga berpotensi terhadap penularan penyakit DBD.

Menurut Teori Lawrence Green, ada 3 faktor yang mempengaruhi perilaku kesehatan seseorang., antara lain: faktor predisposisi (predisposing factors) yaitu: sikap, keyakinan, pengetahuan, kepercayaan, nilai dan norma. Sedangkan faktor pendukung (enabling factors) yaitu: adanya sarana prasaran., faktor pendorong (reinforcing factors) yaitu: keluarga, guru, sebaya, petugas kesehatan, tokoh masayarakat, dan pengambil keputusan. Tujuan penelitian ini untuk mengetahui hubungan pengetahuan dan sikap dengan motivai Jumanior dalam tindakan PSN.

\section{METODE}

Penelitian ini merupakan penelitian correlational dengan pendekatan cross sectional. Besar sampel diperoleh 40 responden kader Jumanior di SD Nurul Islam dan SD NU Pare. Tehnik sampling menggunakan purposive sampling. Variabel independen pada penelitian ini adalah pengetahuan dan sikap, variabel dependen adalah motivasi dalam tindakan PSN. Pengumpulan data menggunakan kuesioner.

Variabel pengetahuan, sikap dan motivasi di ukur melalui kuesioner. Data yang diperoleh akan dianalisis menggunakan menggunakan uji statistik correlation spearman's rho dengan $\alpha \leq 0,05$.

\section{HASIL \& PEMBAHASAN}

a. Hasil

Data Umum 
Sebagian besar responden berusia 11 tahun, perempuan, kelas 4 . Hasil analisis uji homogenitas pada data umum menggunakan Independent sample t test (usia, kelas) dan kruskall wallis (jenis kelamin) menunjukkan seluruh data umum homogen.

\section{Data Khusus (variabel yang diteliti)}

\section{Pengetahuan Jumanior}

Dalam Pelaksanaan PSN

Tabel.1 Distribusi frekuensi tingkat pengetahuan Jumanior dalam peleksanaan PSN, Mei 2016

\begin{tabular}{ccc}
\hline $\begin{array}{c}\text { Tingkat } \\
\text { Pengetahuan }\end{array}$ & Jumlah & $\%$ \\
\hline Baik & 10 & 25,00 \\
\hline Cukup & 22 & 55,00 \\
\hline Kurang & 8 & 20,00 \\
\hline Jumlah & 40 & 100 \\
\hline
\end{tabular}

Data tingkat pengetahuan Jumanior mengenai tindakan PSN pada tabel.1 menunjukkan bahwa mayoritas responden, yaitu 22 anak (55\%) mempunyai tingkat pengetahuan tentang tindakan PSN dalam kategori cukup, $25 \%$ dalam kategori baik dan 20 $\%$ dalam kategori kurang.

2. Sikap Jumanior Terhadap Tindakan PSN, Mei 2016

Tabel.2 Distribusi frekuensi sikap Jumanior terhadap pelaksanaan PSN, Mei 2016

\begin{tabular}{ccc}
\hline Sikap & Jumlah & \% \\
\hline Baik & 11 & 27,50 \\
\hline Cukup & 19 & 47,50 \\
\hline Kurang & 10 & 25,00 \\
\hline Jumlah & 40 & 100
\end{tabular}

Tabel. 2 menunjukkan bahwa mayoritas responden (47,50\%) mempunyai sikap yang cukup terhadap tindakan PSN, 27,50\% dalam kategori baik dan 25\% dalam kategori kurang.

3. Motivasi Jumanior Dalam Pelaksanaan PSN, Mei 2016

Tabel.3 Distribusi frekuensi motivasi Jumanior dalam pelaksanaan PSN, Mei 2016

\begin{tabular}{ccc}
\hline Motivasi & Jumlah & \% \\
\hline Tinggi & 13 & 32,50 \\
\hline Sedang & 16 & 40,00 \\
\hline Rendah & 11 & 27,50 \\
\hline Jumlah & 40 & 100 \\
\hline
\end{tabular}

Tabel. 3 menunjukkan bahwa mayoritas responden mempunyai motivasi dalam kategori sedang yaitu sebanyak $40 \%$, motivasi dalam kategori tinggi $32,5 \%$ dan motivasi dalam kategori rendah sebanyak 27,5\%

4. Tabulasi Silang Distribusi frekuensi Pengetahuan dan Motivasi Jumanior Dalam Tindakan PSN

Tabel.4 Tabulasi silang pengetahuan dan motivasi Jumanior dalam pelaksanaan PSN, Mei 2016

\begin{tabular}{cccc}
\hline $\begin{array}{c}\text { Pengeta } \\
\text { huan }\end{array}$ & \multicolumn{2}{c}{ Motivasi } & Jumlah \\
\cline { 2 - 3 } & Tinggi & Sedang & Rendah
\end{tabular}

\begin{tabular}{lcccc}
\hline Baik & 10 & - & - & 10 \\
\hline Cukup & 3 & 14 & 5 & 22 \\
\hline Kurang & - & 2 & 6 & 8 \\
\hline Jumlah & 13 & 16 & 11 & 40 \\
\hline
\end{tabular}

Tabel. 4 menunjukkan bahwa Jumanior dengan tingkat pengetahuan baik yang mempunyai motivasi tinggi sebanyak 10 orang.

\section{Tabulasi Silang Distribusi}




\section{frekuensi Sikap dan Motivasi Jumanior Dalam Tindakan PSN}

Tabel.5 Tabulasi silang sikap dan motivasi Jumanior dalam pelaksanaan PSN, Mei 2016

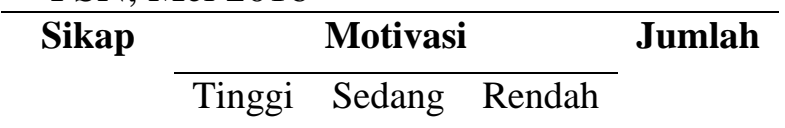

\begin{tabular}{ccccc}
\hline Baik & 11 & - & - & 11 \\
\hline Cukup & 2 & 12 & 5 & 19 \\
\hline Kurang & - & 4 & 6 & 10 \\
\hline Jumlah & 13 & 16 & 11 & 40 \\
\hline
\end{tabular}

Tabel 5 menunjukkan bahwa hampir sebagian Jumanior dengan sikap cukup mempunyai motivasi dalam kategori sedang.

\section{b. Pembahasan}

1. Hubungan Pengetahuan Dan Motivasi Jumanior Dalam Tindakan PSN

Hasil analisis yang dilakukan menunjukkan $\mathrm{p}$-value $=0,002$ pada $\alpha=$ 0,05 . Hal ini menunjukkan terdapat hubungan yang positif dan signifikan antara pengetahuan Jumanior dengan motivasi dalam tindakan PSN dengan kekuatan hubungan dalam kategori kuat (koefisien korelasi) $=0,733$. Hal ini berarti semakin tinggi pengetahuan Jumanior maka semakin tinggi motivasinya dalam melaksanakan tindakan PSN.

Kondisi ini terkait dengan kecakapan yang dimiliki Jumanior, pengetahuan yang baik akan mendorong Jumanior semakin cakap dan termotivasi dalam melaksanakan tindakan PSN. Motivasi merupakan faktor pendorong bagi seseorang untuk bertindak, semakin kuat dorongan yang dimiliki maka semakin mudah seseorang untuk bergerak. Pengetahuan Jumanior tersebut tidak terlepas dari pengalaman Jumanior dalam bentuk pengalaman langsung maupun pengalaman tidak langsung. Tingkat pengetahuan Jumanior dalam penelitian ini cenderung cukup, namun masih terdapat Jumanior yang memiliki pengetahuan dalam kategori kurang. Hal ini disebabkan karena beberapa materi tentang PSN telah disampaikan pada program UKS dan kegiatan ekstrakurikuler "Dokcil".

$$
\text { Menurut Teori Lawrence }
$$

Green, ada 3 faktor yang mempengaruhi perilaku kesehatan seseorang., antara lain: faktor predisposisi (predisposing factors) yaitu: sikap, keyakinan, pengetahuan, kepercayaan, nilai dan norma. Sedangkan faktor pendukung (enabling factors) yaitu: adanya sarana prasaran., faktor pendorong (reinforcing factors) yaitu: keluarga, guru, sebaya, petugas kesehatan, tokoh masayarakat, dan pengambil keputusan.

Faktor-faktor yang mempengaruhi perilaku baik yang berasal dari diri individu maupun dari luar individu tidak akan membentuk perilaku tertentu apabila individu yang bersangkutan tidak mempunyai niat atau minat untuk melakukan perilaku tersebut. Perilaku seseorang ditentukan oleh niat atau minatnya. Niat atau minat merupakan prediktor terbaik dari perilaku. Jika ingin mengetahui apa yang akan dilakukan seseorang, cara terbaik untuk meramalkannya adalah dengan mengetahui niat atau minat orang tersebut. Seseorang individu dapat mempunyai beberapa keyakinan terhadap suatu obyek dan tindakannya sangat dipengaruhi oleh atau berkaitan dengan minatnya.

Motivasi adalah dorongan dari luar dan dalam masing-masing individu untuk mencapai suatu tujuan yang telah ditetapkan. Jumanior sebagai kader di Sekolah yang memiliki peran tinggi dalam tindakan PSN demam berdarah dengue diharapkan mampu memberikan contoh yang baik kepada siswa lain yang kurang memiliki motivasi dalam melakukan pemberantasan sarang nyamuk demam 
berdarah dengue. Kurangnya motivasi seseorang atau masyarakat terhadap penanggulangan dan pencegahan penyakit demam berdarah akan menyebabkan semakin besar kemungkinan timbulnya penyakit demam berdarah dengue. Pemberantasan sarang nyamuk demam berdarah dengue dapat dimulai dari membersihkan lingkungan sekitar rumah. Saat ini kesadaran masyarakat terutama dalam hal memperhatikan kebersihan lingkungan tempat tinggal masih dirasakan sangat kurang.

Penelitian ini sesuai juga dengan Handoko dan Yuli (2007), bahwa motivasi merupakan keaadaan dalam diri pribadi seseorang yang mendorong keinginan individu untuk melakukan kegiatan-kegiatan tertentu guna mencapai suatu tujuan. Motivasi adalah apa yang ada pada seorang yang akan mewujudkan suatu perilaku yang diarahkan pada tujuan mencapai sasaran kepuasan. Motivasi Jumanior dalam pelaksanaan PSN dipengaruhi oleh pengetahuan. Pengetahuan tidak hanya diperoleh melelalui jenjang pendidikan formal, melainkan dari berbagai penyuluhan dan media massa. Pengetahuan diperoleh dari pendidikan yang direncanakan dan tersusun secara baik, maupun informasi yang tidak tersusun secara baik. Apabila dalam pemberian informasi tentang materi mengenai pemberantasan sarang nyamuk secara baik dan benar serta dapat dipahami dan dimengerti oleh Jumanior, menimbulkan sikap atau tindakan perilaku positif dan akan bersifat langgeng. Pengetahuan yang baik tentang pentingnya pemberantasan sarang nyamuk akan memotivasi Jumanior untuk menjaga kesehatan baik di lingkungan keluarga maupun di lingkungan Sekolah.

Hasil penelitian ini sesuai dengan penelitian sebelumnya yang dilakukan oleh Sari (2012) bahwa ada hubungan antara pengetahuan dan sikap. Semakin tinggi pengetahuan seseorang tentang DBD, semakin baik sikap mereka terhadap pencegahan dan pemberantasan penyakit DBD. Untuk itu diperlukan usaha dari pemerintah untuk meningkatkan pengetahuan masyarakat agar ada peningkatan perilaku pemberantasan sarang nyamuk demam berdarah dengue. Usaha-usaha itu bisa melalui iklan layanan masyarakat di radio, televisi, dan Koran.

\section{Hubungan Sikap Jumanior Dengan Motivasi Dalam Pelaksanaan PSN}

Hasil analisis yang dilakukan menunjukkan $\mathrm{p}$-value $=0,014$ pada $\alpha$ $=0,05, \quad \mathrm{CC}=0,724$, yang berarti terdapat hubungan yang positif dan signifikan antara sikap Jumanior dengan motivasi dalam pelaksanaan PSN. Koefisien korelasi tersebut menurut Sugiyono (2008) menunjukkan hubungan yang kuat dan positif, yang berarti semakin baik sikap Jumanior maka semakin tinggi pula motivasi yang dimiliki. Sikap merupakan indikasi kemauan untuk bertindak, semakin baik sikap yang ditunjukkan oleh Jumanior maka motivasi dalam pelaksanaan PSN akan semakin tinggi pula. Sikap Jumanior yang baik akan meningkatkan motivasinya dalam pelaksanaan PSN, sebalikanya sikap yang kurang akan berdampak terhadap penurunan motivasi Jumanior dalam pelaksanaan PSN.

Pemberantasan sarang nyamuk demam demam berdarah dengue dapat dimulai dari lingkungan tempat tinggal seperti rumah. Salah satu fungsi keluarga yang ada adalah fungsi perilaku, dimana kesehatan antar anggota keluarga dapat dinilai lewat 
perilaku dalam kehidupannya, yang didukung dengan tingkat pengetahuan yang baik. Perilaku yang baik untuk menjaga lingkungan yang sehat dan bersih dari sarang nyamuk dapat terwujud apabila motivasi dari seluruh anggota keluarga juga baik.

Kelompok Anak merupakan bagian kelompok masyarakat yang mempunyai peran strategis dalam masyarakat karena jumlahnya sekitar $20 \%$ dari penduduk Indonesia. Peran serta Anak usia sekolah dalam Jumanior

(Jumantik Junior) yang berada di Kecamatan Pare Kabupaten Kediri kurang optimal dan cenderung belum terbentuk kader Jumanior. Pembentukan kader Jumanior sangat penting untuk menanamkan Perilaku Hidup Bersih Sehat (PHBS) pada usia dini sehingga dapat digunakan dasar pemikiran saat dewasa nanti. Usaha menggerakkan anak sekolah lebih dini akan lebih mudah dilakukan dari pada orang dewasa.

Pengetahuan dapat mempengaruhi sikap seseorang. Jumanior yang memiliki pengetahuan baik akan melakukan sikap yang baik pemberantasan sarang nyamuk. Hal ini sesuai dengan teori Wawan dan Dewi (2010) bahwa komponen pembentuk sikap yaitu komponen kognitif (pengetahuan, pandangan, keyakinan), komponen afektif (rasa senang atau tidak senang terhadap objek), komponen konatif (perilaku). Media massa juga merupakan faktor penting penentu sikap, dalam pemberitaan surat kabar maupun radio, berita yang disampaikan faktual harusnya objektif cenderung dipengaruhi sikap penulisnya, akibatnya berpengaruh terhadap sikap konsumennya.

Sikap merupakan konsep paling penting dalam psikologi sosial yang membahas unsur sikap baik sebagai individu maupun kelompok. Banyak kajian yang dilakukan untuk merumuskan pengertian sikap, proses terbentuknya sikap, maupun perubahan. Banyak pula penelitian telah dilakukan terhadap sikap kaitannya dengan efek dan peranannya dalam pembentukan karakter dan sistem hubungan antar kelompok serta pilihan-pilihan yang ditentukan berdasarkan lingkungan dan pengaruhnya terhadap perubahan (Wawan dan Dewi, 2010). Handoko Yuli

menyatakan bahwa motif yang ada pada seseorang akan mewujudkan suatu tingkah laku yang diarahkan pada tujuan mencapai sasaran kepuasan. Jadi motif bukanlah sesuatu yang dapat diamati, dan disaksikan. "Motivasi dikatakan sebagai energi untuk membangkitkan dorongan dalam diri (drive arousal). Motivasi merupakan kondisi yang menggerakkan seseorang agar mampu mencapai tujuan dari motifnya. Dengan adanya motivasi yang tinggi dapat memberikan energi dalam diri seseorang untuk melakukan pemberantasan sarang nyamuk lebih baik (Suharti S, 2010). Hal ini sesuai dengan pendapat Nasir, Ibrahim et all (2014) motivasi adalah perubahan energi dalam diri seseorang yang ditandai feeling dan didahului dengan tanggapan terhadap adanya tujuan. Dari pengertian tersebut motivasi mengandung tiga elemen yaitu : (1) Mengawali adanya perubahan energi, (2) Munculnya rasa, (3) Dirangsang karena adanya tujuan, sehingga motivasi adalah sebagai suatu yang komplek.

Menurut David Mc. Clelland teori motivasi dibagi menjadi tiga macam yaitu : 1) motif berprestasi, yaitu dorongan untuk mencapai sukses dalam berkompetensi dengan standar sendiri selalu berusaha meningkatkan 
kemampuan dalam mewujudkan citacitanya, 2) Affiliasi, yaitu dorongan untuk bersahabat untuk diterima orang lain dan bersatu, pegawai yang bermotif affiliasinya diterima, diakui dan dihargai

orang lain., 3) motif berkuasa, yaitu dorongan yang timbul dalam diri seseorang untuk menguasai atau mempengaruhi orang lain.

Pada penelitian ini, motivasi Jumnior dalam tindakan PSN merupakan gabungan dari tiga motif motivasi seperti yang disampaikan oleh Mc. Clelland, yakni : 1. Motif berprestasi (kader Jumanior yang merupakan perwakilan siswa dapat dikatakan sebagai siswa pilihan akan berupaya untuk berkompetisi dalam melakukan PSN dengan sebaikbaiknya, 2. Affiliasi (beberapa siswa yang tergabung dalam kader Jumanior akan saling bekerjasama dalam PSN di Sekolah karena mereka merasa bila melakukan tugas PSN dengan baik maka akan selalu di akui sebagai Kader Jumanior yang merupakan siwa pilihan, 3. Motif berkuasa (kader Jumanior sebagai wakil siswa bertanggung jawab untuk mensosialisasikan materi PSN yang telah didapatkan kepada siswa lain yang tidak menjadi kader Jumanior atau kepada siapapun yang belum mengetahui tentang PSN baik di Lingkungan sekolah maupun di lingkungan rumah.

\section{KESIMPULAN}

\section{Simpulan}

1. Motivasi Jumanior dalam pelaksanaan PSN berhubungan dengan pengetahuan yang dimiliki dengan tingkat hubungan dalam kategori kuat. Semakin tinggi pengetahuan yang dimiliki oleh Jumanior, maka akan semakin termotivasi dalam indakan PSN.
2. Motivasi Jumanior dalam pelaksanaan PSN berhubungan dengan sikap yang dimiliki, dengan kekuatan hubngan dalam kategori kuat. Semakin baik sikap yang dimiliki Jumanior, maka akan semakin tinggi motivasinya dalam pelaksanaan PSN

\section{Saran}

1. Kegiatan PSN dimasukkan dalam materi UKS atau ekstrakurikuler yang bergerak di bidang kesehatan, sehingga dapat menjadi media informasi bagi siswa yang dalam hal ini berperan penting sebgai change agent kesehatan di lingkungan rumah maupun sekolah.

2. Penelitian selanjutnya dapat dikembangkan ke arah perilaku Jumanior dalam kegiatan PSN agar didapatkan hasil yang komprehensif.

\section{DAFTAR PUSTAKA}

Dinas Kesehatan Kabupaten Kediri, 2015. Kediri Waspada Demam Berdarah. Kediri http://dinkes.kedirikab.go.id/?hal= dbet\&id=7 ( diakses tanggal 21 Februari 2015).

Hardayati W, Mulyadi A, Daryono. 2013. Analisis Perilaku Masyarakat Terhadap Angka Bebas Jentik dan Demam Berdarah Dengue di Kecamatan Pekanbaru Kota, Riau. Program Studi Ilmu Lingkungan. Program Pascasarjana Universitas Riau, Pekanbaru. Jurnal_ISSN 19785283.

Nasir RA, Ibrahim E, Manyyulei S. 2014. Hubungan Pengetahuan dan Sikap Masyarakat dengan Tingkat Kepadatan Larva Aedes Aegypti di wilayah endemis DBD Kota Makassar. Program Kesehatan Lingkungan Fakultas Kesehatan Masyarakat Unhas. 
Sugiyono. 2008. Metode Penelitian Kunatitatif Kualitatif dan R\&D. Bandung. Alfabeta

Handoko,Yuli. 2007. Perilaku Pemberantasan Sarang Nyamuk di Masyarakat. Prodi Keperawatan Blora Poltekkes Kemenkes Semarang Unnes. Jurnal_ISSN 1858-1196.

Sari W, Kurniawan P.T. 2012. Hubungan Tingkat Pengetahuan dan Perilaku PSN Dengan Keberadaan Jentik Aedes Aegypti di Desa Ngesrep Kecamatan Ngemplak Kabupaten Boyolali. Prodi Kesehatan Masyarakat Fakultas Ilmu Kesehatan UMS. Jurnal_ISSN 1979-7621

Suharti S. 2010. Hubungan Pengetahuan dan Motivasi Dengan Perilaku Kepala Keluarga Dalam Pemberantasan Sarang Nyamuk Demam Berdarah Dengue (Di Wilayah Kerja Puskesmas Loa Ipuh Kabupaten Kutai Kartanegara). Thesisi Ilmiah. Surakarta. Magister Kedokteran Keluarga UNS.

Wawan A \& Dewi M. 2010. Teori dan Pengukuran Pengetahuan, Sikap dan Perilaku Manusia. Yogyakarta : Nuha Medika.

Judarwanto, Widodo. 2007. Beberapa Karakteristik Aedes aegypti Sebagai Vektor utama Demam Berdarah. Bagian parasitologi, Fakultas Kedokteran Universitas Udayana. Cermin Dunia Kedokteran No.27 
Afian, Widayati, Setyorini: Pengembangan Model Motivasi Jumanior (Juru

Pemantau Jentik Junior) Dalam Perilaku Psn (Pemberantasan Sarang Nyamuk)

Aedes Aegepty Berbasis Integrasi Model Lawrance Green Dan Mc. Clelleand 